\title{
The Very Idea of Applying Economics: The Modern Minimum-Wage Controversy and Its Antecedents
}

\author{
Thomas C. Leonard
}

Disagreements among economists rarely breach the academy's walls. The recent minimum-wage controversy is a significant exception. At first glance, all the sound and fury is a puzzle. ${ }^{1}$ Minimum-wage effects, at least for current U.S. magnitudes, are small potatoes. ${ }^{2}$ Of several more important policy concerns-entitlement reform, health insurance, CPI calculation, for example-none has generated anything like the vituperation that has characterized the minimum-wage controversy. But if the minimum-wage controversy is not especially important to the economy, it is very important to economics, and, thereby, to the status of economics as a policy science.

Correspondence may be addressed to Professor Thomas C. Leonard, Department of Economics, Fisher Hall, Princeton University, Princeton, NJ 08544; e-mail: tleonard@ princeton.edu. I am grateful to Jeff Biddle, Bob Goldfarb, an anonymous referee, and participants in the 1999 HOPE conference on the history of applied economics for helpful comments on an earlier draft of this material.

1. In the wake of Card and Krueger 1995, one Nobel laureate intoned, "I tremble for my profession" (Miller 1996). Another made reference to "camp-following whores" (Buchanan 1996). A third eminence called Card and Krueger's main interlocutors, David Neumark and William Wascher, "heroes" (Barro 1996).

2. Even a 27 percent increase in the U.S. minimum wage (from $\$ 3.35$ to $\$ 4.25$, in 1990 and 1991) affected only about 8 percent of the labor force, and these workers were concentrated in the retail trade and food service sectors. Ignoring employment effects, Card and Krueger estimate that $\$ 5.5$ billion was transferred to low-wage workers, only 0.2 percent of total U.S. annual earnings $(1995,277)$. Card and Krueger estimate that if firms had passed along all of the labor cost increases to consumers, prices would have increased (once and for all) only about 0.3 percent (393). 
The reason, I want to argue, is that the core of modern economicsneoclassical price theory-is seen to be at stake. In particular, minimumwage research has come to be seen as a test of the applicability of neoclassical price theory to the determination of wages and employment. The modern minimum-wage controversy is not just a technical quarrel over the sign and magnitude of wage-elasticity coefficients; it is the latest chapter in a longstanding methodological dispute over whether and in what domains neoclassical price theory can be said to properly apply. One does not make opposition to minimum wages a disciplinary litmus test, unless there is something this important at stake. ${ }^{3}$

The modern minimum-wage controversy engages economists because it brings to light methodological issues ordinarily submerged in the course of normal science. I present a history of the economics of minimum wages designed to illuminate two such issues: (1) does prevailing theory explain and predict the determination of wages and employment, and (2) by what means do economists decide when explanation and prediction are successful?

The history - really three vignettes - is designed to show, first, that the current debate is a modern-dress version of an old family argument in economics. Second, it provides some evidence for my claim that the minimum-wage controversy is not merely a substantive disagreement among labor specialists, but also a recurring touchstone for methodological debate about the application of economics.

\section{What Is the Modern Minimum-Wage Controversy About?}

The modern minimum-wage controversy derives from a recent literature in empirical labor economics, which argues, foremost among several claims, that moderate increases in mandated minimum wages do not lead to adverse employment outcomes for low-wage workers. ${ }^{4}$ Many of these findings are collected or summarized in David Card and Alan Krueger's

3. George Stigler said in 1976 that "one evidence of professional integrity of the economist is the fact that it is not possible to enlist good economists to defend ... minimum wage laws" (Stigler 1982, 60).

4. Card and Krueger say that their "strongest and most important finding" is the absence of disemployment effects from moderate increases in minimum wages $(1995,387)$. The qualifier "moderate" is important. No economist believes that fixing a wage floor at $\$ 100$ per hour would not create disemployment. Card and Krueger also recognize that the intensity of the minimum-wage debate is out of proportion to its economic importance $(1995,395)$. 
influential 1995 book, Myth and Measurement: The New Economics of the Minimum Wage (hereafter cited as Myth).

The current controversy arises because "the new economics of the minimum wage" is at odds with neoclassical price theory, which predicts disemployment, and with a generation of time-series econometric research, which consistently finds evidence of disemployment effects. Myth's findings are also at odds with what most U.S. economists, especially labor economists, believe (Whaples 1996). Card and Krueger understand this; indeed, they expressly conceive of their project as a refutation of neoclassical price theory's predictions and of the econometric evidence adduced in support (1995, 396-97).

Following the contemporary emphasis, I focus on employment and welfare effects: do minimum-wage increases disemploy low-wage workers, and do minimum-wage increases, on balance, help lowwage workers? Later I take up the less emphasized but essential matter of distribution: To what extent do workers affected by minimum-wage legislation live in poor or near-poor households?5

\section{The Neoclassical Theory of Minimum-Wage Effects}

The neoclassical theory is familiar. Mandated minimum wages are treated as any other price floor. If the mandated wage exceeds the market-clearing wage, then, given a downward-sloping labor demand curve, firms reduce the quantity of labor demanded. The magnitude of the reduction depends upon the wage increase and the wage elasticity of labor demand, but the direction of change is unambiguous. Welfare effects also depend upon the wage elasticity of demand. Some workers will receive the higher wage and are better off. Other workers, those whose product is worth less than the new minimum, will be laid off, or will work fewer hours. If the quantity of labor refers to employment, then the wage gains of those who keep their jobs must be traded off against the wage losses of those who lose their jobs. ${ }^{6}$

5. Poor and near-poor families are those with incomes at or below 1.5 times the U.S. poverty level.

6. Suppose, for example, that the wage elasticity of demand is -0.2 and that the minimumwage increase is 10 percent. This implies that 2 percent of workers (if $L$ is employment) will lose their jobs, and that 98 percent will get a 10 percent raise, meaning that affected lowwage workers collectively realize income gains of 7.8 percent $[(0.98)(0.1)-(.02)(1.00)]$. By implication, minimum wages will help the class of affected workers when the wage elasticity 
Disemployment is a logically necessary result if one assumes that (1) firms maximize profits and (2) the low-skilled labor market is competitive, that is, that firms have no monopsony power (Kennan 1995). Neoclassical theory can accommodate a weakening of assumption 2. If labor markets are monopsonistic, firms exercise their market power and pay a wage lower than workers' marginal revenue product $\left(\mathrm{MRP}_{\mathrm{L}}\right)$. Monopsonistic firms offer higher wages to attract new hires, which leads to costlier labor expenditures (more pay to the inframarginal workers) and inefficiently low employment.

In principle, then, a judiciously chosen minimum wage (set between monopsony wage and $\mathrm{MRP}_{\mathrm{L}}$ ) can increase employment and efficiency. In practice, however, labor economists traditionally regard monopsony as an empirical curiosum (Brown 1988, 134 n. 1). ${ }^{7}$ Individual low-wage firms typically employ a small percentage of the low-wage work force (Brown, Gilroy, and Kohen 1982, 489), so monopsony power is seen as limited in practice. 8

Neoclassical economics is less able to accommodate a weakening of the profit-maximization assumption, which is more fundamental. With few exceptions (see, for example, Prasch 1996), contemporary economists maintain the profit-maximization assumption, generally reverting to monopsony models derived from efficiency-wage explanations.

If some firms pay more than the going wage, and profit maximization is assumed, then the only remaining explanation is that some firms find it profitable to pay above the going rate, which defines an efficiency-wage explanation (Krueger and Summers 1988). Efficiency-wage accounts propose that wages can exceed $M R P_{L}$ when (1) higher wages bring forth greater worker productivity, a reversal of the traditional causality,

is less elastic than -1.0 . But there are two important caveats. First, not all affected workers get a 10 percent raise; those between the old and new minima get a smaller increase. Second, wage elasticities generally derive from studies that calculate employment effects for entire demographic groups, not just for the minimum-wage workers within those groups. Thus, an elasticity estimate such as -0.2 measures the effect of minimum-wage increases on the employment of some group (say, teenagers), which includes higher-wage (hence unaffected) workers, and thereby underestimates the employment effects on the lowest-wage workers. (These points are due to Neumark, Schweitzer, and Wascher 1998, 3-4).

7. Robert Whaples finds that "six out of seven labor economists believe that 'few American workers are employed in monopsonistic labor markets"” (1996, 726).

8. Even with monopsony power, the range of employment-increasing wage increases is limited. A minimum set above the $\mathrm{MRP}_{\mathrm{L}}$ at the monopsonist's profit-maximizing output also results in disemployment. 
(2) there is an informational asymmetry such that firms cannot readily monitor worker effort, and (3) firms have high recruitment and turnover costs (the last is emphasized by Card and Krueger 1995, 373-79). Since profit maximization and perfect competition entail disemployment with higher minima, it is not surprising that, historically, both assumptions recur in arguments against and for the minimum wage.

\section{History of Minimum-Wage Legislation and Its Economics}

The idea of administered wages is ancient. Wage payments to laborers were conventional and noncontractural long before the industrial revolution and the concomitant rise of freely contracting labor. But the idea of administered wages as a legal means of improving the lot of the urban working poor has its origins in nineteenth-century reform movements, especially in the United Kingdom. Minimum wages were connected to mid-Victorian-era trade union movements and were an important item on the Fabian socialist agenda to "democratize" unregulated industries and improve working conditions (Webb and Webb [1897] 1920). 9

The first laws setting wage floors, as against a fixed wage or an outputprice peg, have their origin in Australasia. The District Conciliation Boards of New Zealand, established in 1894 principally for arbitration of labor disputes, had statutory authority to set minimum wages (Douglas 1919, 701). The first independent legal agencies designed specifically for setting minimum wages were established by the 1896 Factory and Shops Act, enacted by the state of Victoria to fix minimum wages in "sweated" industries (701). 10 Britain passed the Trade Boards Act of 1909, which likewise set minimum wages in several industries deemed to be "sweating."

9. A minimum wage means only that workers cannot legally accept a wage below it. Higher wages are legal. How and in what settings the minimum is to be fixed is more ambiguous, as the compelling but vague term living wage suggests. See Pigou 1922.

10. Definitions of "sweating" vary. Reporting on the 1888-90 investigation of "sweated industries" by a select committee in the British House of Lords, Beatrice Webb offers the following definition: "Lord Derby and his colleagues decided that sweating was no particular method of remuneration, no particular form of industrial organization, but certain conditions of employment-viz., unusually low rates of wages, excessive hours of labor, and unsanitary workplaces. When we get any one of these conditions in an exaggerated and extreme form, ... then we may say, that the labor is sweated, and that the unfortunates are working under the sweating system" (cited in Holcombe 1910, 574). 
The late-nineteenth-century minimum-wage movement in the United States was originally voluntarist in spirit. Organizations like the National Consumers League hoped, by information provision and moral suasion, to persuade consumers to avoid firms that paid especially low wages to workers - a minimum wage was seen as a moral rather than a legal standard (Kelley 1912). State legislation overtook their efforts. Massachusetts (1912) was the first, followed a year later by Wisconsin, Minnesota, Washington, Oregon, California, Colorado, Nebraska, and Utah (see Millis 1914).

Some laws empowered supervisory boards to determine minimum wages; others directly fixed minima by statute. In all cases, the states' laws, unlike their British Commonwealth precursors, applied to women and minors only. Until the advent of a federal minimum in 1938, men were deemed outside such paternal protection, in light of the U.S. Constitution's explicit protection of the right to free contract.11

Stretching back into the classical era is the question of whether a general theory - that of free markets and how they determine price and quantity - can be applied to matters of wage and employment determination. In other words, is it the case, as Adam Smith said, that the market for men is like the market for goods, so that there exists a "labor market" in which wages are determined as prices are in other markets? At least as early as John Stuart Mill, we see a further application of this application: what does the general "free market" model, as applied to the workers and employers' behavior, tell us about the effects of a particular policy measure, the wage floor?

Mill's 1848 political economy text has a recognizably modern argument on employment effects. Ignoring the peculiarities of Mill's wages-fund doctrine, which he had yet to abandon, the outline of the neoclassical disemployment argument is present 150 years ago. Said Mill:

If law or opinion succeeds in fixing wages above this [competitive] rate, some laborers are kept out of employment; as it is not the intentions of the philanthropists that these should starve, they must be provided for. $(1848,432)$

Minimum wages will disemploy some workers, says Mill, and something must be done to help the newly disemployed. But, whatever is done

11. For a brief history of the dramatic political events leading up to the Fair Labor Standards Act (FLSA), see Grossman 1978. 
to help—public assistance, for example—will create a disincentive to work.

Mill points to the now familiar efficiency cost of all interventionsthe tension between alleviating poverty and providing incentives to work. If laid-off workers receive a guaranteed income, then there is no incentive to work unless the minimum wage is well above this level. But if the minimum is so set, previously viable jobs are eliminated, which is wasteful (Kennan 1995).

The disemployment argument is in place, as is a familiar theme of British political economy: unintended policy consequences. The sundry social reform movements of nineteenth-century Britain generally regarded Mill's late classical economics as a kind of vulgar laissez-faire, a mere ratification of the raw excesses of Victorian industrial capitalism. But Mill was an ardent social reformer. He quarreled not with the goal of meliorating adverse free-market outcomes, but with the efficacy of policy instruments such as a legal minimum.

Henry Sidgwick (1886) shared Mill's skepticism regarding the net benefits of government interventions, especially utopian socialist schemes (see Hutchison 1953, 53-54). And Sidgwick was at pains to distinguish British political economy from more truly laissez-faire approaches, such as Claude-Frédéric Bastiat's. British political economy does not argue that low-wage workers get what they deserve, but that well-intentioned interventions may do more harm than good. Says Sidgwick:

You can make it illegal to employ a man under a certain rate of wages, but you cannot secure his employment at that rate, unless the community will undertake to provide for an indefinite number of claimants work remunerated at more than its market value; in which case its action will tend to remove, to a continuously increasing extent, the ordinary motives to vigorous and efficient labor. $(1886,631)$

In an 1897 article by Alfred Marshall, the disemployment argument is also quite clear: "[The academic economist] must for instance analyse the methods which people are tempted to take for securing a high minimum wage ... and must show which of them will have indirect effects that will cause workingmen as a whole a loss greater than the benefit. ... ordinary people do not see that the means most commonly advocated . . . would impoverish all" $(1897,128)$. Here, in an address to the inaugural meeting of the Cambridge Economics Club (29 
October 1896), we also find Marshall elevating efficiency as the badge of the academic economist. The economist must fight conventional wisdom on minimum wages, says Marshall, not because one disagrees with the goal of alleviating poverty among the working poor, but because minimum wages do more harm than good $(1897,129)$.

The Marshallian theory of minimum wages finds its most thorough and lucid exposition in a 1907 essay by H. B. Lees Smith; it is a remarkable paper written in partial response to minimum-wage arguments in Sidney and Beatrice Webb's Industrial Democracy ([1897] 1920). I present Lees Smith's argument truncated and translated into modern argot, but it bears reading in the original.

At the outset, Lees Smith assumes that productivity is independent of cost: "we may assume for the present that the efficiency of both wageearners and employers is the same before and after the enactment of the minimum" $(1907,504)$. He notes that statutory coverage may be partial or total, taking partial coverage first.

If the minimum is actually binding, higher labor costs must be funded from reduced expenditures on other inputs, higher output prices, or lower profits (504). Take reduced expenditures first. If other inputs such as skilled labor are substitutes, and they generally are, then a binding minimum will increase, not decrease, their prices and expenditures thereon, which eliminates other input costs as a means of funding higher costs of low-skilled labor (505).

If, alternatively, output prices are increased to fund higher low-skilled labor costs, then output demand will fall, unless such demand is perfectly inelastic. And, if firms and workers are already optimizing, the reduction in output quantity demanded will entail an inefficient reallocation of inputs to other uncovered sectors (506). Thus, present in Lees Smith is the law of demand and the assumption of profit maximization:

A rise in the price of the commodity will lead to a decrease in the demand for it. This means that a certain amount of the labor and capital hitherto employed in the production of the commodity must seek other occupations. But this is likely to involve both the laborers and the employers in a loss. Employers and laborers were presumably occupied where, with such choices as they had, they thought they would do the best for themselves. . . . It is no kindness to the workers in a trade to merely turn them out. (506; emphasis added) 
Finally, increased wages may be funded out of profits. But if profits are diminished by higher labor costs, capital will migrate to more remunerative sectors. This will occur unless the covered sector's output market is so uncompetitive that supranormal profits can fund the higher labor costs, a claim nowhere made by minimum-wage proponents.

Thus, each possible alternative entails low-skilled labor being disemployed. With universal coverage, the same outcome obtains, only low-skilled labor becomes unemployed or leaves the labor force. Concludes Lees Smith: the disemployment verdict of "pure theory" is clear. Lees Smith fully anticipates the neoclassical argument, as exemplified by Stigler 1946.

I do not wish to suggest that political economists were uniformly opposed to minimum wages. Not only is it anachronistic to assume that economics was, around 1900, a uniform or even professionalized discipline, but, all along the way, there were those who denied that late-classical and then Marshallian models applied to labor markets. F. D. Longe (1894), who was one of the first to challenge Mill's wagesfund doctrine, dissented, as did a number of American Institutionalists, notably John R. Commons, who helped draft the first Wisconsin minimum-wage statute.

Perhaps the most conspicuous proponents of minimum wages in this era are Beatrice and Sidney Webb. Sidney Webb (1912) offers an especially useful counterpoint to Lees Smith 1907.

Webb argues that, for the least productive workers, wages are not determined by labor productivity. He says, "The wages of the lowest grade of labor are fixed, not by 'worth' in any sense-not even the possible 'value in exchange' - of the individual laborer, but (as we nowadays sadly concede) largely by the urgent necessities of the 'marginal' man, or, rather, the 'marginal' woman" $(1912,990)$. By implication, either low-wage firms are not profit maximizing, or they find it profitable, along efficiency-wage lines, to hire workers whose productivity is very low.

Webb makes recourse to both claims. At one point he says that "a Legal Minimum positively increases the productivity of the nation's industry, by ensuring the surplus of unemployed workmen shall be exclusively the less efficient workmen ... [which] is plainly not the case under "free competition"' (979). For this to be true, firms cannot be, $e x$ ante, profit maximizing, so Webb is offering, in rough form, an early version of the "shock-therapy" argument. 
Arguing in the alternative, Webb also makes an efficiency-wage argument. "To put it plumply," he says, "if the employers paid more, the labor would be worth more" (990). Why might higher productivity follow higher wages? At one point Webb argues that affected firms will be obliged to innovate- " [the minimum wage] acts as a constant incentive to the further improvement of the manual laborers, the machinery and the organizing ability used in industry"-implicitly assuming, as against Lees Smith, that factor substitution would not, on balance, work against low-skilled workers (985). Webb also argues that if the minimum were to increase wages above subsistence, laborers will be physically stronger and thus more productive. This latter claim requires that firms had failed to perceive that a wage above subsistence would increase profitability.

What we observe, then, is that Webb takes issue with the key ideas in Lees Smith's account, not least profit maximization and perfect competition. Webb also argues, at least implicitly, against the law of demand. Where Lees Smith insists that higher output prices will entail lower output quantity demanded, Webb suggests that "the community [consumers] would willingly pay more for it, and yet consume as much, or nearly of much of it as it now does" (990).

I do not wish to suggest that Webb and Lees Smith would have described their disagreement solely in terms of profit maximization and labor market structure. The hope, rather, is that this sketch suffices to show that the leading contemporary issue in minimum-wage economics-employment effects - is already being debated in familiar terms around the turn of the century. The disemployment account is recognizable in Mill 150 years ago, and, in the sense of considering the labor-market conditions under which disemployment does and does not obtain, is almost fully formed 90 to 100 years ago.

What is missing from the minimum-wage arguments of this era is empirical evidence. The evidence for the successful application of economics to labor markets is entirely theoretical - that is, based on appeal to reason and logic. Clearly, U.S. data became available only following the states' minimum-wage legislation. But what is striking through much of the twentieth century is the extent to which the application of economics to labor markets remains almost entirely theoretical. George Stigler's landmark paper, for example, presents only a few stylized facts for evidence, admitting that "no precise estimate of the effects of the minimum wage upon aggregate employment is possible" $(1946,361)$. 
The mid-twentieth-century debate recapitulates many of the old arguments about whether the general theory of competitive markets, now full-blown neoclassical price theory, is applicable to labor markets. But, here our second theme emerges: the role of empirical evidence as the arbiter of which theory (if any) is indeed applicable. The marginalist controversy and the economics of minimum wages come together in the person of Richard Lester.

\section{Minimum Wages and the Marginalist Controversy}

Richard Lester, the labor economist to whom Card and Krueger dedicate their book, argued that firms do not always maximize profits and that labor markets generally are not competitive. Lester's conclusion was based on surveys of manufacturing CEOs who did not know marginal costs and revenues, and on wage surveys, which found a wide variance in wages paid to production workers of roughly equal productivity (Lester 1946a, 1946b). Lester read ignorance of marginal magnitudes as implying that firms do not maximize profits; and he read the unexplained wage variation as suggesting that firms do not take wages as given.

Lester was not the first to argue that firms do not maximize profits, 12 but his work generated a volley of neoclassical responses, an exchange which has come to be known as the marginalist controversy. Some responses were directed at Lester's challenges explicitly (Machlup 1946, 1947; Stigler 1947) and others more indirectly (Alchian 1950; Friedman 1953). ${ }^{13}$ It was Lester's investigation of labor markets, and his strong conclusions, that gave rise to a withering exchange on the nature of economic theory and on the role of empirical evidence in testing theories and their implications.

That labor research was the occasion for the methodological dispute we ordinarily associate with the marginalist controversy is not coincidence. Lester and other institutionally minded labor economists of the mid-century era-especially John Dunlop, Clark Kerr, and Lloyd

12. R. L. Hall and C. J. Hitch $(1939,18)$ interpret their interviews of businessmen as arguing that firms do not equate marginal revenues and marginal costs, but use rules of thumb for marking up average costs.

13. Lester's rejoinder to Machlup 1946 (itself a reply to Lester 1946a) and reply to Stigler 1946, the neoclassical locus classicus, are found in Lester 1947. 
Reynolds (DKLR) - practiced a kind of labor economics that differed significantly from the neoclassical labor economics that later predominated (Freeman 1989, 317-42). The DKLR method was built around institutional expertise, detailed case studies, and surveys of management and workers. They surely resented what they regarded as neoclassical theory-tropism: relative indifference to empirical work, and hostility to survey questionnaires in particular (Machlup 1946).

Related, and perhaps more important, DKLR rejected the neoclassical model's assumptions of profit maximizing and perfect competition, at least for empirical purposes.

The labor market is not a bourse; wage rates are typically quoted prices. (Dunlop 1944, cited in Freeman 1989, 330)

The labor market is by nature an imperfect instrument. . . . all kinds of wage distortions exist even under non-union conditions. (Reynolds and Taft 1956, 168, cited in Freeman 1989, 319)

Reasoning about labor markets as though they were commodity markets seems to be an important explanation for erroneous conclusions on such matters as minimum wages. (Lester 1947, 146, responding to Stigler 1946)

A [competitive market-determined wage structure] is a useful norm for theoretical speculations but an unstable departure point for empirical studies. (Kerr 1977, 46, cited in Freeman 1989, 318)

In short, DKLR disagreed with the neoclassical presumption that labor markets, especially the determination of wages and employment, operate no differently than do goods markets.

The controversy following Lester's challenge had methodological consequences that reverberate still. Fritz Machlup's 1946 response to Lester 1946a was important less for its argument that Lester's survey methodology was sloppy, than for its methodological claim that profit maximization is not a descriptive claim but a useful fiction. Managers may not know marginal magnitudes, nor need they be calculating on all conceivable margins. But their habits and routines can be thought of as learned strategies that themselves derive from a goal of profit maximization. Methodologically, it is as if firms maximize profits (Machlup 1946). 
Alchian (1950) added a natural selection story to the gap that Machlup opened between intent and effect. Whether or not firms intend to maximize profits, Alchian argued, a Darwinian business environment ensures that surviving firms will be maximizing profits, as underperforming firms are weeded out by competition. It is a competitive output market structure that creates profit maximizing behavior, albeit as a by-product rather than as the necessary goal of firms.

Milton Friedman's famous paper (1953) borrowed elements from both Machlup 1946 and Alchian 1950. With Machlup, Friedman embraced the as if method, which he inflated into a grander claim: theoretical assumptions need not be true. While it is clearly unrealistic to assume that billiard players solve systems of differential equations when making shots, it is useful for prediction, says Friedman, to pretend that they do. Friedman goes so far as to make "unrealistic" (read: false) assumptions into a theoretical virtue: "The more significant the theory, the more unrealistic the assumptions" (1953, 14).

From Alchian, Friedman carries over the idea that an agent's intent is unimportant; economics should be seen not as a theory of motivational states but of market outcomes. Friedman concedes that firms need not intend to maximize profits, but boldly argues that this does not matter methodologically. Theories are to be judged not by the truth or falsity of their assumptions, but, rather, by the success of their predictions. The assumption that firms consciously optimize is false, he concedes, but the prediction that only profit-maximizing firms will survive in the long run is empirically accurate.

Methodologically, the realism-of-assumptions debate is something of a muddle. Our focus is on the role of empirical results in adjudicating among competing theories. Much turns on whether one sees assumptions as restricting the applicability of the theory-a domain assumption - or whether one sees assumptions' truth or falsity as negligible for theoretical purposes, such as prediction (Musgrave 1981).

If we regard the assumption of competitive labor markets as a domain assumption, then the disemployment prediction obtains only when the assumption is true, that is, only when labor markets are competitive. Stigler's reply to Lester 1946a at one point reverts to just this domainassumption interpretation $(1947,155) .14$ Alternatively, one can predict

14. Joan Robinson, parenthetically commenting on the minimum-wage debate, connects the matter of assumptions to the Marshallian-era version of the controversy: "This [monopsony] analysis may throw light on the dispute between Marshall and Mr. and Mrs. Webb upon the 
disemployment regardless of whether the competitive-market assumption is true or not, a negligibility assumption. If the power of firms to set wages below $\mathrm{MRP}_{\mathrm{L}}$ is negligible, then the falsity of the assumption will not much matter because, ceteris paribus, the disemployment prediction will still be borne out. This is Friedman's interpretation of how assumptions work in economics.

Both readings have important implications for application. Since Stigler agrees that assumptions constrain the applicability of theory, then it is clearly important that assumptions not be too restrictive; otherwise, there is nothing to apply to. But Stigler, of course, does not really attend to the question of whether maximization and competition are overly restrictive assumptions. As we have seen, his own contribution offers only limited empirical evidence. And he is quite dismissive of Lester's attempt to empirically test the key assumptions.

In any event, it was Friedman's reading that carried the day: economists need not worry about the truth or falsity of assumptions; only predictive accuracy matters. By implication, empirical work should be confined to testing the predictions of theory. ${ }^{15}$ Testing of assumptions, of the kind that Lester has undertaken, can be dismissed as methodologically beyond the pale.

Although Friedman prevailed, his methodological injunction-empirically test theoretical predictions-went mostly unheeded. With few exceptions (e.g., Peterson 1957), the relative lack of mainstream empirical work on minimum-wage effects persists well into the 1970s. Robert Goldfarb's survey (1974) of the minimum-wage literature finds that the empirical support for disemployment effects, especially for adults (ages twenty and up), who have generally composed the majority of low-wage workers, is quite limited. With the exception of teenage employment, it is not hyperbole to suggest that, in the Nixon era, the basis for professional priors was essentially unchanged from that of three generations earlier.

'marginal productivity theory' of wages (see [Marshall's] Principles, 705). It seems to have arisen because Mr. and Mrs. Webb failed to realized the implications of the assumptions of perfect competition, while Marshall failed to recognize the extreme unreality of those assumptions" (Robinson [1933] 1950, 300-301 n. 2).

15. I do not take up Friedman's implicit claim that theoretical components are separable, that is, that there is a meaningful distinction between theoretical assumptions and theoretical implications. 


\section{Empirical Evidence on Employment Effects of Minimum Wages}

The empirical literature grew rapidly with the expansion of time-series econometric techniques. Roughly twenty-five papers are reviewed in Charles Brown, Curtis Gilroy, and Andrew Kohen's (1982) survey. Goldfarb (1981) reports empirical progress, especially with regard to distribution effects.

Most empirical papers in this period make use of a regression with something like the following specification:

$$
Y=f\left(M W, D, X_{1} \ldots X_{n}\right),
$$

where $Y$ is labor force status (e.g., labor force participation ratio, employment-population ratio, unemployment rate), $M W$ is some measure of the minimum wage, $16 \mathrm{D}$ is a business cycle variable to account for changes in aggregate economic activity, and $X_{i}$ is an exogenous variable controlling for labor supply, school enrollment, participation in the armed forces, and so on (Brown, Gilroy, and Kohen 1982, 497). Some specifications add a time trend as well (see Mincer 1976). There are different functional forms to the specifications, but nearly all studies use Current Population Survey (CPS) data.

Brown, Gilroy, and Kohen summarize the literature as follows: teenage employment-rate elasticities are on the order of -0.1 to -0.3 , but "the lower half of that range is to be preferred." For young adults (ages 20-24), the effect of the minimum wage on employment is "negative and smaller" than that for teens. But Brown, Gilroy, and Kohen are careful to say that "uncertainty about the effects on [older] adults is a serious gap in the literature ...," echoing Goldfarb 1974 (1982, 524). These conclusions generally comport with contemporaneous surveys and collections (Rottenberg 1981; Report of the Minimum Wage Study Commission 1981; Eccles and Freeman 1982).

The uncertainty surrounding adult employment effects notwithstanding, the disemployment prediction seems comfortably consolidated by the 1980s (Alston, Kearl, and Vaughan 1992). There may have been

16. "The key variable, minimum wage, has generally been measured by the ratio of the nominal legal minimum wage to average hourly earnings weighted by coverage, as devised by Kaitz (1970). Ratios of minimum wage rates to average hourly earnings are calculated for each industry, weighted by the proportion of workers covered. These are combined into an index in which the weight for each industry ration is the number of persons employed in the industry as a percentage of total employment" (Brown, Gilroy, and Kohen 1982, 499). 
quibbles about the exact magnitude of disemployment effects, but none about whether they existed (Deere, Murphy, and Welch 1995, 232). Indeed, there was very little empirical work on minimum wages undertaken during the mid-eighties. What changed?

First, the few new time-series estimates which did incorporate data from the eighties seemed to suggest that employment elasticities with respect to minimum wages were becoming more inelastic. Second, while the nominal value of the federal minimum wage stayed at $\$ 3.35$ per hour between 1981 and 1990, several states raised their minima, which created a research opportunity for cross-sectional studies. Finally, the increase in income inequality during the 1980s spurred political action for redistributive measures. In the nineties, minimum-wage research revived, and with dramatic consequences.

\section{The "New" Economics of Minimum Wages and Its Critics}

I emphasize two lines of attack that Card and Krueger mount on the neoclassical account. First, they present cross-sectional evidence from four studies-most famously from the New Jersey-Pennsylvania (NJPA) fast food experiment-which finds that the employment elasticity of the minimum wage is positive, or at least nonnegative. Of Myth's seven analyses of employment effects, one shows zero effect and six show positive effects, but only two of these are significantly different from 0 at the 0.05 level $(1995,388)$.

Second, and less well known, Card and Krueger review the established econometric literature and judge it altogether inadequate. They conclude that previous findings are unreliable, tainted by publication bias and specification search. Paul Osterman calls this aspect of Myth "a damning indictment of how labor economics has been practiced over the past three decades" $(1995,839)$. Card and Krueger offer their own empirical approach-"natural experiment" and "model-free empiricism"-as evidentially superior to earlier econometric studies.

Card and Krueger's Evaluation of Previous Empirical Work

Card and Krueger (CK) review earlier empirical work on minimumwage effects and judge it inadequate and tendentious. CK replicate and 
extend some earlier work, finding that employment elasticities attenuate when more recent years are included. A meta-analysis of previous timeseries estimates concludes that earlier work is corrupted by publication bias and specification search.

CK argue that time-series estimates, over time, involve larger and larger samples, which, ceteris paribus, should increase $t$-statistics. If the additional data in newer studies are independent of the older data, "then a doubling of the sample size should result in an increase in the absolute value of the $t$-ratio of about 40 percent" $(1995,187) .17$ If the $t$ statistics do not increase with sample size, then, CK suggest, something is fishy. Using the time-series studies reviewed in Brown, Gilroy, and Kohen 1982, CK find that the $t$-statistics are, in fact, declining in sample size (188). 18

CK also conduct a related meta-analysis that compares the relationship between the estimated coefficients of employment elasticity with their respective standard errors, for the same set of time-series studies. If the estimated coefficients $(b)$ are truly unbiased, CK argue, then there should be no systematic relationship between them and their respective standard errors ( $s e$ ). If, on the other hand, editors will only publish studies with robust test statistics ( $t>2$, say), then this publication bias should be reflected in the meta-analysis, given that $t=b / s e$. Plotting "implicit" standard errors against the coefficients, CK find a rather good fit (for $b=2 s e$ ), with only two or three exceptions, suggesting a problem with independence $(1995,191)$.

From this meta-evidence, CK offer three possible explanations. One explanation is that structural change made the employment effects of minimum wages decline over time. But structural change calls into question the validity of time-series work to begin with. The alternative

17. Card and Krueger note the lack-of-independence problem that occurs with time-series data more generally, but point out that previous authors themselves assume independence following adjustments for serial correlation in errors and similar procedures.

18. Actually, they plot the absolute value of the $t$-statistic against the square root of the degrees of freedom, or $(n-k)^{1 / 2}$. The rationale is explained by Kennan 1995. The $t$-statistic in a regression with $n$ observations on $k$ explanatory variables satisfies the equation $t^{2}(n-k)=r^{2} /\left(1-r^{2}\right)$, where $t$ is the $t$-statistic of a regressor and $r$ is the partial correlation coefficient between this regressor and the dependent variable. As the sample size increases, $r$ converges to its population value, assuming stationarity of the partial correlation, so $t$ must grow at the same rate as the square root of $n-k$ (Kennan 1995, 1963). 
explanations are specification search and publication bias. CK argue that the early literature was contaminated by a preference (on the part of data-mining researchers and biased editors) for statistically significant results that comported with the disemployment predictions of the neoclassical model.

The econometric specifications which became standard were chosen, CK suggest, because they produced the desired negative sign and got the $t$-statistics above 2. Later researchers tended to reuse these specifications. Because true statistical significance was overstated in the earlier research, however, more recent work (presumably not so susceptible to temptation) discovered weaker effects (1995, 192-93). Three of Finis Welch's studies are singled out by CK as examples of this econometric malpractice.

Natural Experiments and "Model-Free"

Empiricism

Myth is notable for its emphasis on natural experiments (NE) and, more generally, the idea of "model-free" empirical work. CK take the NJPA study as their most important result, precisely because they believe that its setting is closest to the ideal of the randomized controlled experiments of the "hard" sciences. They imply that an NE, even if an imperfect substitute for a randomized controlled experiment, is evidentially superior to traditional econometric techniques.

The New Jersey-Pennsylvania (NJ-PA) study compares employment responses in the fast-food market in New Jersey and eastern Pennsylvania to increases in the minimum wage (New Jersey raised its state minimum from $\$ 4.25$ to $\$ 5.05$, while Pennsylvania's remained at $\$ 4.25$ ). The "experiment" compares the employment effects on affected workers against the Pennsylvania "control" group. If all differences between New Jersey and Pennsylvania remain unchanged before and after the minimum-wage increase, then any employment $\left(E_{i t}\right)$ "difference in differences" $(D D)$ can be attributed to the minimum-wage effects, as follows:

$$
D D=\left(E_{\mathrm{NJ} 2}-E_{\mathrm{PA} 2}\right)-\left(E_{\mathrm{NJ} 1}-E_{\mathrm{PA} 1}\right),
$$

where period 1 is February 1992 (before the new minimum takes effect in April 1992) and period 2 is November 1992. Neoclassical theory predicts that, ceteris paribus, employment in New Jersey should fall 
relative to employment in Pennsylvania, that is, that $D D$ will be negative. CK, however, find it to be positive. 19

CK sometimes make extravagant claims regarding the significance of this finding, even as they are careful to acknowledge the relative weaknesses of NEs. First, NEs do not randomly assign subjects into treatment and control groups, which is essential for attributing any differential outcomes to the minimum wage exclusively. Minimum-wage legislation is the outcome of a political process, and states that enact minimum wages may differ from those that do not; they may have more robust economic growth, for example $(1995,23)$. Second, NEs are not "blind." Subjects know when they are (or are not) being treated. Third, NEs require ceteris paribus. Any current differences between treatment and control groups must persist in the absence of the minimum-wage intervention (e.g., both groups should exhibit identical rates of growth) (23).

$\mathrm{CK}$ are confident that these departures from classical experiments are small relative to the advantage NEs provide over traditional econometric approaches. The NE approach is "model free" in that its results do not hinge on a particular econometric specification or, therefore, upon the theoretical assumptions that underwrite a given specification. And, at least in principle, NEs can reduce the incentive for specification search, the temptation to fit the model to the data.

\section{Replies to Card and Krueger}

The replies to Myth are too numerous to document fully, a measure of its influence. Professional critics have focused less on the nature than on the execution of CK's empirical methods, especially in the famous NJ-PA study.

The most serious replies are as follows: (1) the survey is poorly designed as reflected in the noisy data that result (Kennan 1995; Welch 1995); (2) the study is not a proper NE, particularly with respect to the control group (Hamermesh 1995; Kennan 1995; Welch 1995); (3) results are short run only (Hamermesh 1995); (4) employment increases should mean higher output and lower output prices, but CK find evidence of higher output prices (Brown 1995); and, most conspicuously,

19. Employment is measured in full-time equivalents (FTEs), where a part-time worker is counted as 0.5 FTE. The results: $2.7=[21.0-21.2]-[20.4-23.3]$. 
(5) results cannot be replicated and are contradicted when superior data are employed (Neumark and Wascher 1995).20

Low-wage employers may well have already adjusted to the New Jersey minimum-wage increase before it took effect in April 1992, given that the statute passed in 1990. Or their adjustment may have occurred after the second survey. And the replication by David Neumark and William Wascher (1995) does contradict CK's original work.21 And CK's most important result - that employment in New Jersey increases relative to employment in Pennsylvania-obtains principally because employment fell in Pennsylvania, the control. It is, John Kennan argues, "like having a drug trial in which the drug has no effect but the placebo makes people sick" $(1995,1958)$.

\section{Conclusion: The Very Idea of Applying Economics}

The "new" economics of the minimum wage is not really new at all. Although Card and Krueger do not mention it, their method of natural experimentation has direct empirical antecedents in a little-known statistical literature developed in the 1910s and 1920s. There are large repositories of "before and after" employment data collected by the U.S. Bureau of Labor Statistics and by various state agencies.22 And Card and Krueger's empiricism and their monopsony explanation have acknowledged affinities with the DKLR approach. But two things do distinguish the contemporary controversy: (1) the substantive emphasis on employment effects and (2) the methodological emphasis on empirical work as the arbiter of successful theoretical application.

As the debate over minimum wages increasingly stresses its role as a test of the applicability of price theory to labor markets, there is a concomitant emphasis on employment effects. Reactions by nonspecialists to Myth are almost entirely in this vein. Said one Nobel laureate:

20. A more detailed account is available in Leonard 1997, 268-73.

21. Card and Krueger 1998 replies to Neumark and Wascher 1995.

22. Kennan 1995 instances a remarkably detailed study of minimum-wage effects in Oregon (Obenauer and von der Nienburg 1915), which begins, "Does the establishment of a legal minimum wage for women do more harm than good to the women it is designed to assist?" and which presents employment and wage data for tens of hundreds of affected girls and women. The BLS published eleven bulletins on minimum-wage issues prior to Obenauer and von der Nienburg 1915, and there are detailed data in numerous state publications, such as National Industrial Conference Board 1927. 
Just as no physicist would claim that "water runs uphill," no selfrespecting economist would claim that increases in the minimum wage increase employment. Such a claim, if seriously advanced, becomes equivalent to a denial that there is even minimal scientific content in economics, and that, in consequence, economists can do nothing but write as advocates for ideological interests. (Buchanan 1996)

Labor specialists are less intemperate but equally preoccupied with disemployment. Myth examines many consequences of minimum wages, but CK themselves make central their own findings and their critique of previous econometric work on employment effects.

The emphasis on employment has crowded out a crucial, and answerable, policy question: Do minimum wages reduce poverty? A desire to help the working poor, of course, lies at the root of minimum-wage policy. An obviously relevant question is, Are affected workers poor? (Stigler 1946). ${ }^{23}$ The surprising answer is, generally, no. The reasons for a positive but weak relationship between minimum wages and household income are well understood and well documented (Gramlich 1976).

The relationship is weak when low-wage workers are members of nonpoor households (teens, say), or when households have nonwage income, or when households have no workers at all. Low-wage workers are more likely to be in poor families than are all workers, but the great majority of low-wage workers are not poor. Ralph Smith and Bruce Vavrichek (1987) found that 75 percent of affected workers in 1985 were neither poor nor near-poor. CK's own distribution analysis finds that only 30 percent of affected workers live in poor and near-poor families $(1995,280)$. In other words, over two-thirds of income redistributed by minimum-wage increases-even assuming zero disemployment-will go to individuals in families neither poor nor near-poor.

Myth concludes, "We believe that our findings suggest a reorientation of policy discussions away from the efficiency aspects of the minimum wage and toward distributional issues" (393). But, at the same time, CK are obliged to say that the minimum wage is a "blunt instrument" for redistributing income to poor families and find that "the effect of

23. Not all economists accept alleviation of poverty as the goal of minimum wages. Some argue that flattening the income distribution is worthwhile for its own sake, and others suggest that progressive income redistribution stimulates aggregate demand, owing to a higher propensity to consume in lower-income households (Prasch 1996). 
the minimum wage on the overall poverty rate of adults is statistically undetectable" (1995, 285, 280; see also Burkhauser, Couch, and Wittenberg 1996). ${ }^{24}$ Even if one believes that minimum-wage increases do not disemploy low-wage workers, or is prepared to suffer disemployment as a cost of redistribution, it is significant that minimum wages do so little for the goals of poverty reduction or progressive income redistribution. The evidence on distribution-where the data are comparatively reliable and uncontroversial—has been completely overshadowed by the emphasis on whether the disemployment prediction obtains.

The methodological emphasis on empirical work as the arbiter of successful theoretical application is also new to the contemporary period. Friedman (1953), we have seen, made testing of theoretical predictions the paramount goal of economic science, but only in the contemporary controversy does empirical work actually assume this role. CK are explicit: they regard their work not merely as four papers contributing to a large empirical literature, but as "a simple and direct test of the kind of theoretical reasoning that economists routinely apply to other, more complicated phenomena" $(1995,397)$.

Some are prepared to renounce Myth on a priori grounds. Evidence that says "water runs uphill" is to be rejected on its face. But labor is the quintessentially empirical field in economics. Labor economists take pride in their willingness to submit theoretical claims to the tribunal of empirical evidence. In other corners of economics, such as macroeconomics, says Richard Freeman, "the evidentiary base is sufficiently diffuse to allow economists with different priors to reach different conclusions-to make a lawyer's case as it were" $(1995,831)$. But, Freeman argues, not so in minimum-wage research, where changes occur in discrete exogenous jumps, and evidence permits far less scope for "disparate interpretation" (831).

Nearly all labor specialists in the controversy, critics and supporters alike, take for granted (at least nominally) that attempts to apply theory must be tested by empirical evidence. CK's valedictory to Myth says that "although many economists may disagree with our interpretation of the findings in this book, we hope that they will at least agree on the value of testing the implications of standard economic theory, and on the validity of our empirical approach" $(1995,399)$. Their hope has been met. I can

24. A minimum wage can help only the employed. Card and Krueger $(1995,305)$ estimate that about two-thirds of adults in poor families do not work at all. Burkhauser, Couch, and Wittenberg $(1996,551)$ estimate that fully one-quarter of poor families have no working adults. 
locate no serious objection, even among CK's strongest critics, to the idea of empirical evidence as testing theory or to the evidential virtues of natural experiments. But a methodological ambivalence persists. If all agree that the data should be decisive, no one agrees on when the data are decisive.

I conjecture that the ambivalence regarding empirical testing has two sources. One is methodological. To answer the key substantive question-do Myth's results refute price theory's disemployment prediction?-one must know the answer to a prior methodological question: what evidence constitutes a refutation? If Myth really offers "a simple and direct test" of neoclassical price theory, then one must know what counts as a simple and direct test. Without methodological argument, still less consensus, there are no ready means for evaluating CK's claim.

The other source of ambivalence derives from a residual unease with the robustness of the empirical evidence on disemployment. The evidence for adults, we have seen, was never as strong as that for teenage workers. Furthermore, CK's most contentious claim-that the entire empirical literature before circa 1990 is contaminated by econometric malpractice-has gone virtually unrebutted. The silence is fairly deafening. The only paper to directly take issue with CK's extraordinary indictment is Neumark and Wascher 1996.25

Finally, good evidence on minimum-wage effects is hard to obtain, even given the relatively advantageous NE setting, as Kennan 1995 points out. Even ignoring legal noncompliance and survey measurement error, there are thorny problems. First, employers can respond to wage increases by reducing nonpecuniary compensation-health insurance, training, pleasant work environment, scheduling flexibility, discounts on goods and services. This simply rearranges the composition of the worker's pay packet and should not affect employment (Kennan 1995). Second, employers might reduce hours without reducing employment, so measuring employment will miss changes in labor demand. Third, affected workers already have highly volatile employment patterns. The noise in the employment data makes it difficult to disentangle changes

25. Neumark and Wascher (1996) examine Myth's meta-analysis of the time-series literature and argue that CK's results are better explained by structural change than by publication bias leading to specification search. Parameter values changed, they say, producing spurious evidence of publication bias. Neumark and Wascher do not consider the implications of structural change for the validity of time-series evidence. 
caused by statutory minima from those caused by confounding factors - the proverbial needle-in-the-haystack problem (Kennan 1995).

All of these empirical challenges are well known to labor researchers. But they are troubling. Methodologically, the belief that empirical evidence "decides" when theory applies obviously has less force when the evidence tends to be equivocal. Substantively, if the evidence for minimum-wage effects is equivocal-when, according to its producers, it offers the best of empirical opportunities-then what does this imply about the quality of evidence in economics more generally?

Herein lies a basic disciplinary tension. Modern labor economics is empirical. Indeed, in some respects, Myth can be read as an empiricist manifesto-go forth and test, and if the data are inconvenient for the theory, so much the worse for theory. But modern labor economics is also, unlike its mid-century variant, firmly neoclassical (Freeman 1989, 318). Price theory, like its predecessors, has the goal of producing a general theory of economic behavior, which places the determination of wages and employment comfortably within its purview-markets are markets are markets. And a general theory that does not apply in one domain is not a general theory. These twin disciplinary ambitions-to be an empirical policy science, and to have a general theory of economic behavior - can clearly come into conflict, especially when, as with minimum wages, compelling evidence meets core theoretical belief.

The economist's dilemma is as follows: do I reject the evidence or reject the application of theory? Most respondents to Myth have chosen the first option-some on principle, but most on grounds that the new evidence is too fragile to justify abandoning core doctrine. Still others argue that more evidence is required. Kennan says:

Myth and Measurement's lasting contribution may well be to show that we just don't know how many jobs would be lost if the minimum wage were increased to $\$ 5.15$, and that we are unlikely to find out using more sophisticated methods of inference on the existing body of data. What is needed is more sophisticated data. $(1995,1964)$

More sophisticated data are surely desirable. But the conflicting ambitions of economics will continue to manifest themselves in recurring controversy, at least until the data are so sophisticated that economists routinely answer methodological questions such as, What evidence would convince you that your theory is refuted? 


\section{References}

Alchian, Armen. 1950. Uncertainty, Evolution, and Economic Theory. Journal of Political Economy 58.3:211-21.

Alston, Richard, J. R. Kearl, and Michael Vaughan. 1992. Is There a Consensus among Economists in the 1990s? American Economic Review Papers and Proceedings 82.2:203-9.

Barro, Robert. 1996. Higher Minimum Wage, Higher Dropout Rate. Wall Street Journal, 11 January, A14.

Brown, Charles. 1988. Minimum Wage Laws: Are They Overrated? Journal of Economic Perspectives 2.3:133-45.

1995. Comment for review symposium on Myth and Measurement: The New Economics of the Minimum Wage, by David Card and Alan Krueger. Industrial and Labor Relations Review 48.4:828-30.

Brown, Charles, Curtis Gilroy, and Andrew Kohen. 1982. The Effect of the Minimum Wage upon Employment and Unemployment. Journal of Economic Literature 20.2:487-528.

Buchanan, James. 1996. Commentary on the Minimum Wage. Wall Street Journal, 25 April, A20.

Burkhauser, Richard, Kenneth Couch, and David Wittenberg. 1996. "Who Gets What" from Minimum Wage Hikes: A Re-estimation of Card and Krueger's Distributional Analysis in Myth and Measurement: The New Economics of the Minimum Wage. Industrial and Labor Relations Review 49.3:547-52.

Card, David, and Alan Krueger. 1995. Myth and Measurement: The New Economics of the Minimum Wage. Princeton, N.J.: Princeton University Press.

. 1998. A Reanalysis of the Effect of the New Jersey Minimum Wage Increase on the Fast-Food Industry with Representative Payroll Data. NBER Working Paper no. 6386. Cambridge, Mass.: NBER.

Deere, Donald, Kevin Murphy, and Finis Welch. 1995. Employment and the 1990-1991 Minimum-Wage Hike. American Economic Review Papers and Proceedings 85.2:232-43.

Douglas, Dorothy. 1919. American Minimum Wage Laws at Work. American Economic Review 9.4:701-32.

Dunlop, John. 1944. Wage Determination under Trade Unions. New York: Augustus M. Kelley.

Eccles, Mary, and Richard Freeman. 1982. What! Another Minimum Wage Study? American Economic Review Papers and Proceedings 72.2:226-32.

Freeman, Richard. 1989. Labor Markets in Action. Cambridge: Harvard University Press.

. 1995. Comment for review symposium on Myth and Measurement: The New Economics of the Minimum Wage, by David Card and Alan Krueger. Industrial and Labor Relations Review 48.4:830-34.

Friedman, Milton. 1953. The Methodology of Positive Economics. In Essays on Positive Economics. Chicago: University of Chicago Press. 
Goldfarb, Robert. 1974. The Policy Content of Quantitative Minimum Wage Research. Industrial Relations Research Association Proceedings: 27:261-68.

- 1981. The Context of Recent Research. In The Economics of Legal Minimum Wages, edited by Simon Rottenberg. Washington, D.C.: American Enterprise Institute.

Gramlich, Edward. 1976. Impact of Minimum Wages on Other Wages, Employment, and Family Incomes. Brookings Papers on Economic Activity, no. 2:409-51.

Grossman, Jonathan. 1978. Fair Labor Standards Act of 1938: Maximum Struggle for a Minimum Wage. Monthly Labor Review 101.6:22-30.

Hall, R. L., and C. J. Hitch. 1939. Price Theory and Business Behavior. Oxford Economic Papers, no. 2:13-45.

Hamermesh, Daniel. 1995. Comment for review symposium on Myth and Measurement: The New Economics of the Minimum Wage, by David Card and Alan Krueger. Industrial and Labor Relations Review 48.4:835-38.

Holcombe, A. 1910. The British Minimum Wages Act of 1909. Quarterly Journal of Economics 24.3:574-77.

Hutchison, Terrence. 1953. A Review of Economic Doctrines 1870-1929. Oxford: Clarendon Press.

Kelley, Florence. 1912. Minimum-Wage Laws. Journal of Political Economy 20.10:999-1010.

Kennan, John. 1995. The Elusive Effects of Minimum Wages. Journal of Economic Literature 33.4:1950-65.

Kerr, Clark. 1977. Labor Markets and Wage Determination. Berkeley: University of California Press.

Krueger, Alan, and Lawrence Summers. 1988. Efficiency Wages and the Interindustry Wage Structure. Econometrica 56.2:259-93.

Lees Smith, H. B. 1907. Economic Theory and Proposals for a Legal Minimum Wage. Economic Journal 17.68:504-12.

Leonard, Thomas. 1997. The Reason of Rules in the Intellectual Economy: The Economics of Science and the Science of Economics. Ph.D. diss., The George Washington University.

Lester, Richard. 1946a. Shortcomings of Marginal Analysis for Wage-Employment Problems. American Economic Review 36.1:62-82.

- 1946b. Wage Diversity and Its Theoretical Implications. Review of Economics and Statistics 28.3:152-59.

- 1947. Marginalism, Minimum Wages, and Labor Markets. American Economic Review 37.1:135-48.

Longe, F. D. 1894. The Coal Strike and a "Minimum" Wage. The Economic Journal 4.13:25-34.

Machlup, Fritz. 1946. Marginal Analysis and Empirical Research. American Economic Review 36.4:519-54.

. 1947. Rejoinder to an Antimarginalist. American Economic Review 37.1:148-54. 
Marshall, Alfred. 1897. The Old Generation of Economists and the New. Quarterly Journal of Economics 11.2:115-35.

Mill, John Stuart. 1848. Principles of Political Economy with Some of Their Applications to Social Philosophy. Boston: Little \& Brown.

Miller, Merton. 1996. Commentary on the Minimum Wage. Wall Street Journal, 25 April, A20.

Millis, H. A. 1914. Some Aspects of the Minimum Wage. Journal of Political Economy 22.2:132-55.

Mincer, Jacob. 1976. Unemployment Effects of Minimum Wages. Journal of Political Economy 84.4, part 2: 87-104.

Musgrave, Alan. 1981. "Unreal Assumptions" in Economic Theory: The F-Twist Untwisted. Kyklos 34.3:377-87.

National Industrial Conference Board. 1927. Minimum Wage Legislation in Massachusetts. New York: NICB.

Neumark, David, Mark Schweitzer, and William Wascher. 1998. The Effects of Minimum Wages on the Distribution of Family Incomes: A Non-Parametric Analysis. NBER Working Paper no. 6535. Cambridge, Mass.: NBER.

Neumark, David, and William Wascher. 1995. The Effect of New Jersey's Minimum Wage Increase on Fast-Food Employment: A Reevaluation Using Payroll Records. NBER Working Paper no. 5224. Cambridge, Mass.: NBER.

- 1996. Is the Time-Series Evidence on Minimum Wage Effects Contaminated by Publication Bias? NBER Working Paper no. 5631. Cambridge, Mass.: NBER.

Obenauer, Marie, and Bertha von der Nienburg. 1915. Effect of Minimum-Wage Determinations in Oregon. Bulletin of the U.S. Bureau of Labor Statistics. Number 176. Washington, D.C.: U.S. Government Printing Office.

Osterman, Paul. 1995. Comment for review symposium on Myth and Measurement: The New Economics of the Minimum Wage, by David Card and Alan Krueger. Industrial and Labor Relations Review 48.4:839-42.

Peterson, John. 1957. Employment Effects of Minimum Wages, 1938-1950. Journal of Political Economy 65.5:412-30.

Pigou, A. C. 1922. Trade Boards and the Cave Committee. The Economic Journal 32.127:315-24.

Prasch, Robert. 1996. In Defense of the Minimum Wage. Journal of Economic Issues 30.2:391-97.

Report of the Minimum Wage Study Commission. 1981. Washington, D.C.: U.S. House of Representatives.

Reynolds, Lloyd, and C. Taft. 1956. The Evolution of the Wage Structure. New Haven, Conn.: Yale University Press.

Robinson, Joan. [1933] 1950. The Economics of Imperfect Competition. London: Macmillan.

Rottenberg, Simon, ed. 1981. The Economics of Legal Minimum Wages. Washington, D.C.: American Enterprise Institute. 
144 Thomas C. Leonard

Sidgwick, Henry. 1886. Economic Socialism. Contemporary Review 50 (November): $620-31$.

Smith, Ralph, and Bruce Vavrichek. 1987. The Minimum Wage: Its Relation to Incomes and Poverty. Monthly Labor Review 110.6:24-30.

Stigler, George. 1946. The Economics of Minimum Wage Legislation. American Economic Review 36.3:358-65.

- 1947. Professor Lester and the Marginalists. American Economic Review 37.1:154-57.

. 1982. The Economist as Preacher and Other Essays. Chicago: University of Chicago Press.

Webb, Sidney. 1912. The Economic Theory of a Legal Minimum Wage. Journal of Political Economy 20.10:973-98.

Webb, Sidney, and Beatrice Webb. [1897] 1920. Industrial Democracy. London: Longmans, Green.

Welch, Finis. 1995. Comment for review symposium on Myth and Measurement: The New Economics of the Minimum Wage, by David Card and Alan Krueger. Industrial and Labor Relations Review 48.4:842-49.

Whaples, Robert. 1996. Is There a Consensus among American Labor Economists? Journal of Labor Research 17.4:725-34. 